\title{
PCR-RFLP and genetic diversity analysis of cpDNA in some species of the genus Salvia $\mathrm{L}$.
}

\author{
Rashid Ismael Hag Ibrahim ${ }^{1,2,3}$, Masahiro Sakamoto ${ }^{1}$ and Jun-Ichi Azuma ${ }^{1}$ \\ ${ }^{1}$ Graduate School of Agriculture, Kyoto University, 606-8502, \\ Kitashirakawa Oiwake-cho, Kyoto, Sakyo-ku, Japan; \\ ${ }^{2}$ University of Khartoum, Faculty of Science, Botany Department, \\ PO Box 321, PC 11115, Khartoum, Sudan
}

Author for correspondence: (rihagibrahim@gmail.com)

Received July 19, 2011; accepted September 1, 2011

\begin{abstract}
Long Accurate polymerase chain reaction restriction fragment length polymorphism (LA-PCR-RFLP) of the chloroplast DNA (cpDNA) was used to investigate phylogenetic relationships between 54 species of Salvia L. Two Ocimum L. species were used as an out group. A pair of universal primers in LA-PCR protocol resulted in long cpDNA of an expected size ( $\sim 15$ kilo base pair (kb)) from each Salvia and Ocimum species, except $S$. x superba (hybrid; S. sylvestris x S. amplexicaulis or S. nemorosa). LA-PCR products were separately digested with each of EcoRI, HindIII, PvuII, NdeI, SmaI or MfeI restriction enzymes. S. roemeriana Scheele showed amplified fragment length difference (AFLD). S. roemeriana and/or S. lyrata L. could be identified with any of the enzymes used except $P v u I I$. Identification of Ocimum species from Salvia could be carried out with NdeI, SmaI or $M f e I$. EcoRI and MfeI exhibited more polymorphic and informative patterns than HindIII, PvuII, NdeI or SmaI. LA-PCR-RFLP analysis generated 28 polymorphic restriction fragments. Fragments were visually detected, photographed and used to build a genetic similarity data matrix based on Nei and Li (1979) method. PHYLIP software package (Felsenstein 2005) and the genetic similarity matrix were exploited to construct a phylogenetic tree. The phenogram generated by UPGMA clustering analysis separated Salvia species based on genetic distance into distinct groups obviously dependent on origin.
\end{abstract}

\section{KEYWORDS: Chloroplast DNA, PCR-RFLP, Salvia}

Salvia L. is the largest genus in the Lamiaceae. Salvia species are perennial, biennial, or annual herbs, evergreen or deciduous shrubs (Clebsch 2003). Approximately 900 species of Salvia are distributed worldwide and undergone extensive speciation process in three different regions of the world. Central and South America have about 500 species of the genus and Central Asia and Mediterranean area have about 250 species, while eastern Asia has around 90 species. Most members of the Mentheae tribe are characterized by four stamens, but Salvia has only two stamens (Claßen-Bockhoff et al. 2003). Unusual structure of stamens, diversity in floral morphology, and vegetative habit created some confusion regarding infra-generic boundaries in Salvia and was considered monophyletic (Walker and Sytsma 2007). Bentham`s study (1848; cited by Walker et al. 2004) of Salvia separated the genus into 12 sections. Walker et al. (2004) studied the chloroplast sequences of $t r n \mathrm{~L}-\mathrm{F}$ inter-genic region and $r b c \mathrm{~L}$ gene and found that Salvia is not monophyletic but comprises at least two and possibly three distinct lineages. These lineages were assigned as Clade I of mainly Old World species, Clade II of mainly New World species and Clade III of Asian species.

Chloroplast genomes as well as other organelle genomes evolve slower than nuclear genomes (Palmer 1987). This conservation phenomenon of organelle genomes was exploited to design universal primers that were capable of amplifying polymorphic non-coding regions of cpDNA of some algae, bryophytes, pteridophytes, gymnosperms and angiosperms (Taberlet et al. 1991), non-coding regions of mitochondrial and cpDNA (Demesure et al. 1995), coding regions of cpDNA (Badenes and Parfitt 1995; Tsumura et al. 1996) as well as whole chloroplast genomes (Dhingra and Folta 2005; Ibrahim et al. 2007). A database for some of these primers was created by Heinze (2007).

The cpDNA and its universal primers were important for taxonomic, molecular phylogenetics and evolutionary relationships among diverse taxa as well as to develop species-specific markers. Universal primers have been used to study phylogenetic relations (Gielly and Taberlet 1994; Badenes and Parfitt 1995; Tsumura et al. 1996; Demesure et al. 1996; Parani et al. 2000; Wang et al. 2000; Cronn et al. 2002; Stehlik et al. 2002; Stehlik 2002), species identification (Parani et al. 2001; Ridgway et al. 2003; Tsai et al. 2006, 2008), polymorphic chloroplast microsatellites (Powell et al. 1995; Cato and Richardson 1996; Parducci et al. 2001; Ishii et al. 2001; ArroyoGarcia et al. 2002) and genetic diversity (Parducci and Szmidt 1999; Huang and Sun 2000; Walker et al. 2004).

RFLP analysis of chloroplast genomes is widely used for plant evolutionary studies, particularly at the inter- and intra-specific level and molecular systematics (Strauss and Doerksen 1990; Govindaraju et al. 1992; Wang and Szmidt 1994; Krupkin et al. 1996; Schaal et al. 1998;

\footnotetext{
${ }^{3}$ Current address: Department of Horticulture, Gyeongnam National University of Science and Technology, 150 Chilamdong, Jinju, Gyeongnam 660-758, Republic of Korea
} 
Byrne et al. 2003). PCR-RFLP was applied for the identification of intra-specific variations in the cpDNA of Abies alba (Ziegenhagen et al. 1995), Quercus robur (Dumolin et al. 1995), Fagus sylvatica (Demesure et al. 1996), Ginko biloba (Shen et al. 2005) and Quercus glauca (Shih et al. 2006). It has provided evidence for the presence of inter-specific variations in the cpDNA of the genus Phaseolus (Vekemans et al. 1998), Abies (Parducci and Szmidt 1999), Millet (Parani et al. 2000), Mangrove (Parani et al. 2001), Soybeans (Xu et al. 2001), Papayas (Van Droogenbroeck et al. 2004), and Houttuynia (Wei et al. 2005). It was used for inter-generic studies in Cajanus (Lakshmi et al. 2000).

Some studies relied on coding regions of the cpDNA, others on non-coding regions. Parducci and Szmidt (1999) studied ten different cpDNA regions of the genus Abies. Cronn et al. (2002) investigated four different cpDNA regions of the genus Gossypium. Walker et al. (2004) used the inter-genic region of $t r n \mathrm{~L}-\mathrm{F}$ and $r b c \mathrm{~L}$ gene sequences of the cpDNA to study Salvia and related genera. Degrees of polymorphism may vary substantially across the chloroplast genome due to the presence of micro- and macro-structural rearrangements in some chloroplast genomes. For example, small inversions (Hiratsuka et al.1989), insertions and/or deletions (Ogihara et al. 1991; Kanno et al. 1993; Maier et al. 1995), base substitutions (Morton and Clegg 1995), and translocations (Ogihara et al. 1988), as well as large inversions such as the case of Oenothera elata (Hupfer et al. 2000) and Lotus japonicus (Kato et al. 2000).

The purpose of this study was to explore a long region of the cpDNA of Salvia in contrast to most studies that focused on a single short region or short regions of the cpDNA. This long region of the chloroplast genome of Salvia covers the area from $p s b$ A gene to $r p s 7$ gene and of about 15,031bp long. Design of primers and length estimation were based on the chloroplast genome of Gossypium barbadense L. (Ibrahim et al. 2006).

\section{Materials and Methods}

Plant Material Young leaf samples were collected from naturally grown Salvia (54 species) and two Ocimum species in Kyoto Botanical Garden, Japan (Table 1). Leaf samples were stocked at $-20^{\circ} \mathrm{C}$ until needed for experiments.

DNA Isolation Plant Genomic DNA Extraction Miniprep System (Viogene, USA) was used to isolate total genomic DNA from leaf samples. The manufacturer's protocol was followed. Extracted DNA was the template for LA-PCR amplification.

Primers Design The cpDNA sequence of G. barbadense was the reference for primers design (Ibrahim et al. 2006).

Table 1. Species of Salvia and Ocimum tested in this study

\begin{tabular}{|c|c|c|c|}
\hline No & Species & No & Species \\
\hline 1 & S. tiliifolia Vahl & 29 & S. sinaloensis Fern. \\
\hline 2 & S. verticillata $\mathrm{L}$. & 30 & Ocimium basilicum (Sweet Basil) \\
\hline 3 & S. microphylla Kunth -1 & 31 & Ocimum basilicum 'Green Ruffles' \\
\hline 4 & S. 'purple-majesty' & 32 & S. farinacea Benth. \\
\hline 5 & S. mexicana L. & 33 & S. patens Cav. \\
\hline 6 & S. uliginosa Benth. & 34 & S. 'Anthony-Parker' \\
\hline 7 & S. guaranitica St.-Hil. ex Benth. & 35 & S. chiapensis Fern. \\
\hline 8 & S. elegans Vahl. & 36 & S. discolor Kunth \\
\hline 9 & S. cadmica Boiss. & 37 & S. staminea M. \& A. ex Benth. \\
\hline 10 & S. gesneriiflora Lindley \& Paxton & 38 & S. coccinea L. \\
\hline 11 & S. microphylla Kunth -2 & 39 & S. nemorosa L. \\
\hline 12 & S. leucantha Cav. & 40 & S. lyrata L. \\
\hline 13 & S. 'indigo-Spires' & 41 & S. chamaedryoides Cav. \\
\hline 14 & S. azurea Michx. & 42 & S. involucrata Cav. \\
\hline 15 & S. microphylla Kunth -3 & 43 & S. virgata Jacq. \\
\hline 16 & S. madrensis Seemann & 44 & S. tomentosa Mill. \\
\hline 17 & S. microphylla Kunth -4 & 45 & S. $x$ superba \\
\hline 18 & S. virgata Jacq. & 46 & S. officinalis 'Icterina' \\
\hline 19 & S. pratensis L. & 47 & S. officinalis 'Tricolor' \\
\hline 20 & S. jurisicii Kosanin & 48 & S. argentea $\mathrm{L}$. \\
\hline 21 & S. apiana Jepson & 49 & S. japonica Thunb. Ex Murray \\
\hline 22 & S. roemeriana Scheele & 50 & S. glabrescens Makino \\
\hline 23 & S. regla Cav. & 51 & S. nipponica Miq. \\
\hline 24 & S. melissodora Lagasca & 52 & S. glutinosa L. \\
\hline 25 & S. buchananii Hedge & 53 & S. forsskaolii L. \\
\hline 26 & S. viridis L. & 54 & S. microphylla 'violet' \\
\hline 27 & S. sclarea L. & 55 & S. officinalis L. \\
\hline 28 & S. splendens Sello ex R. \& S. & 56 & S. greggii Gray \\
\hline
\end{tabular}


Table 2. Primers used for LA-PCR amplification of cpDNA from Salvia and Ocimum species

\begin{tabular}{ccccc}
\hline Primer & Sequence & Size (bp) & Position $^{\text {a }}$ & Expected Size (bp) \\
\hline F12 & CGTAATCGATTAGTTAACATGTTGGTTAACCG & 32 & $(146,617) r p s 7$ & \\
R12 & GGTGCCATTATTCCTACTTCTGCAGCTATAGG & 32 & $(01,243) p s b A$ & 14,943 \\
\hline
\end{tabular}

${ }^{a}$ Position and gene name on the chloroplast genome sequence of G. barbadense (Ibrahim et al. 2006)

A pair of primers was selected (Table 2) from the manually designed set that was used before to study cultivated cotton species (Ibrahim et al. 2007).

LA-PCR The manufacturer's (Takara Shuzo, Kyoto, Japan) protocol was followed but half of the recommended volumes of reagents were applied in this experiment. LAPCR amplification of cpDNA was carried out in $200 \mu 1$ thin-walled tubes using 1.25 units of TaKaRa LA Taq ${ }^{\mathrm{TM}}$ polymerase and specific pair of primers. LA-PCR amplification was run in a Bio-Rad iCycler PCR machine (Hercules, CA, USA) under the following conditions: initial denaturizing step at $94^{\circ} \mathrm{C}$ for $1 \mathrm{~min}$, followed by 30 cycles at two different temperature regimes: $98^{\circ} \mathrm{C}$ for $10 \mathrm{~s}$ and $68^{\circ} \mathrm{C}$ for $15 \mathrm{~min}$ as annealing and extension of primers, then a final extension step was applied at $72^{\circ} \mathrm{C}$ for $10 \mathrm{~min}$. Successfully amplified LA-PCR-cpDNA was tested against $10 \mathrm{~kb}$ DNA marker $(\lambda$-HindIII digest; Takara Shuzo, Kyoto, Japan), separated by electrophoresis in $0.8 \%$ agarose gel in $1 \times$ TAE buffer $(40 \mathrm{mM}$ Tris-acetate and $1 \mathrm{mM}$ EDTA), stained with Ethidium bromide $(0.5 \mu \mathrm{g} /$ $\mathrm{ml}$ ), visualized and photographed under FAS-II UVilluminator (Toyobo Co. Ltd., Tokyo, Japan).

DNA Digestion After amplification, $2 \mu$ of each LAPCR-cpDNA were separately digested in total volume of $10 \mu 1$ with one of six restriction enzymes: EcoRI, HindIII, PvuII, NdeI, SmaI or MfeI. The manufacturer's protocol for restriction enzymes was followed (New England BioLabs, UK). Digestion products were then separated along with $1 \mathrm{~kb}$ DNA marker (New England BioLabs, UK) by electrophoresis in $1.5 \%$ agarose gel in $1 \mathrm{xTAE}$ buffer at a constant current of $500 \mathrm{~mA}$ and a voltage of $100 \mathrm{~V}$ for about $1 \mathrm{~h}$. Thereafter, gels were stained in Ethedium bromide solution, visualized and photographed under UV-illuminator.

Data analysis Restriction fragments were analyzed visually and scored as present (1) or absent (0) for each Salvia and Ocimum species to generate a data matrix. Seqboot, Restdist, Neighbour, and Consense are components of the PHYLIP software package (Felsenstein 2005). One thousand sets of bootstraps were performed by Seqboot. Restdist was used to calculate the proportion of shared fragments or so called Genetics Similarities (GS) between each pair of Salvia and/or Ocimum species based on Nei and Li (1979) method, i.e. GS $=2 \mathrm{~N}_{\mathrm{XY}} /\left(\mathrm{N}_{\mathrm{X}}+\mathrm{N}_{\mathrm{Y}}\right) . \mathrm{N}_{\mathrm{X}}$ and $\mathrm{N}_{\mathrm{Y}}$ are the total number of fragments scored in species $\mathrm{X}$ and $\mathrm{Y}$, respectively, and $\mathrm{N}_{\mathrm{XY}}$ is the number of shared fragments between $\mathrm{X}$ and Y. The matrix of pair wise (1GS) values, i.e. the proportion of fragments that were not shared, was the source for Neighbor to construct neighborjoining dendrograms and determine the genetic relationships among Salvia and Ocimum species. Neighbor generated trees were applied to Consense feature. The final tree was edited with TreeView 1.6.6 (Page 1996).

\section{Results}

LA-PCR of CPDNA A pair of primers named F12 and R12 was the start and limit for LA-PCR amplification of a region that spans around $15 \mathrm{~kb}$ of the cpDNA from 54 Salvia and two Ocimum species. Each of 53 Salvia species and two Ocimum species excluding $S$. x superba produced a single long PCR band of the expected size considering the correspondent region from $p s b \mathrm{~A}$ gene to $r p s 7$ gene in the reference chloroplast genome sequence of cotton $G$. barbadense (Ibrahim et al. 2006). S. roemeriana was the only species that produced slightly longer PCR-cpDNA or visually detectable AFLD (Fig. 1).

LA-PCR-RFLP EcoRI, MfeI, HindIII, PvuII, NdeI or SmaI restriction enzymes were used to digest LA-PCR amplified cpDNA of Salvia and Ocimum species. Restriction enzymes EcoRI and $M f e I$ resulted more polymorphic and informative fragments than HindIII, PvuII, NdeI or SmaI. Though, $S$. roemeriana and $S$. lyrata showed different polymorphism, they were easily distinguishable from each other and the rest of species. Therefore, digestion of LA-PCR-cpDNA amplified by F12/R12 primers with one of the enzymes tested except $P v u$ II can be used to identify S. roemeriana and/or S. lyrata (Fig.2; Lanes 22 and 40). Ocimum species showed their difference from Salvia when digestion was carried out with NdeI, SmaI or MfeI (Fig.2; Lanes 30 and 31). Thus, NdeI, SmaI and MfeI enzymes are useful to identify Ocimum species from Salvia based on tested part of cpDNA. Shimada and Sugiura (1991) reported that the chloroplast genomes of higher plants are highly conserved. Wagstaff et al. (1995) analyzed restriction site variation of cpDNA in Nepetoideae (Labiateae) subfamily and reported Ocimum species as a basal genus for salvia. Highly conserved cpDNA in higher plants especially related genera may explain the similarity of tested Ocimum and Salvia species. Fig. 2 illustrates LA-PCR amplified cpDNA digested with MfeI. Table 3 shows restriction enzymes and number of resultant fragments from digestion of amplified LA-PCR cpDNA of Salvia and Ocimum species. 

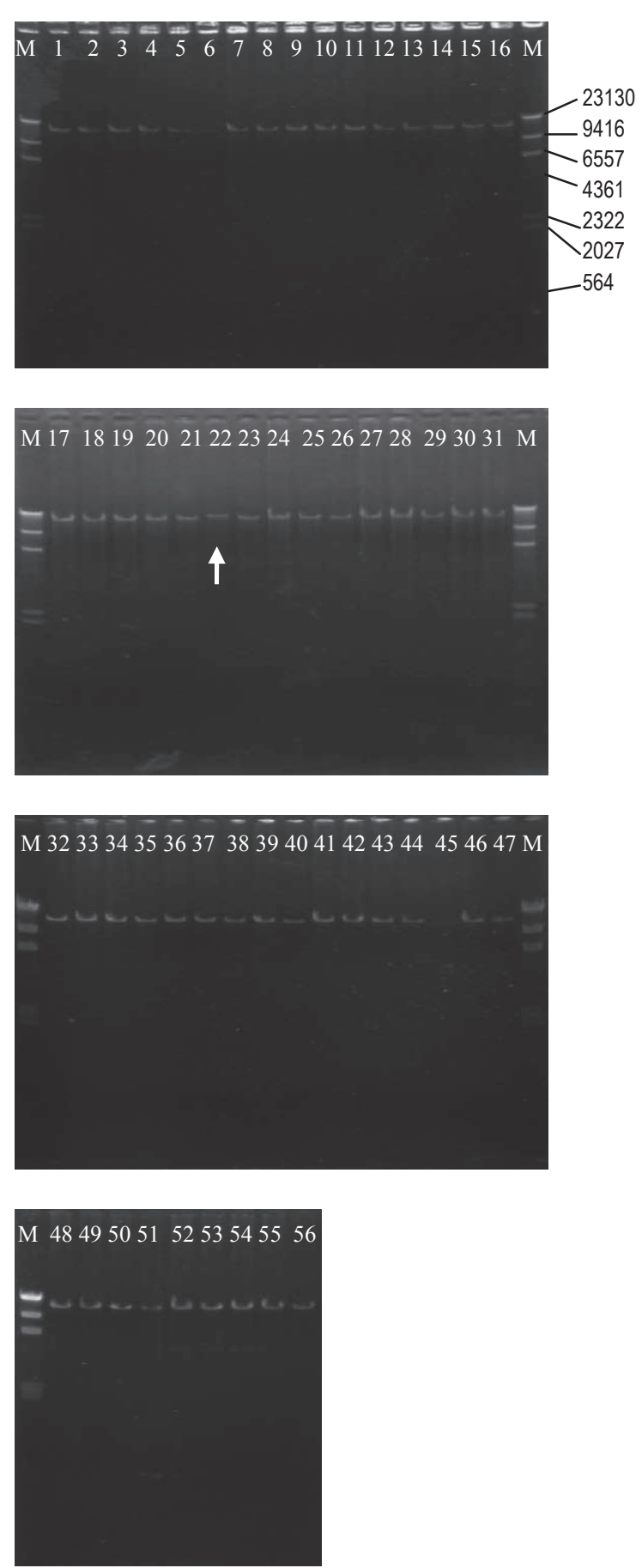

Fig. 1. Undigested LA-PCR products amplified by F12/ R12 primers from the chloroplast genomes of Salvia species (Lanes 1 29 and 32 56) and two Ocimum species (Lanes 30 and 31). Numbers 1-56 indicate the names of Salvia and Ocimum species as listed in order in Table 1. The AFLD from $S$. roemeriana (Lane 22) appeared a little longer than PCR products of other species (arrow). M is $\lambda$-HindIII digest DNA ladder marker (Takara Shuzo, Kyoto, Japan).

Phylogenetic analysis PHYLIP software package was the tool to analyze the collected data from LA-PCR-RFLP of the cpDNA from Salvia and Ocimum species. The resultant phylogenetical tree is shown in Fig. 3. The data file was bootstrapped 1000 times before proceeding. Ocimum species were an out group.
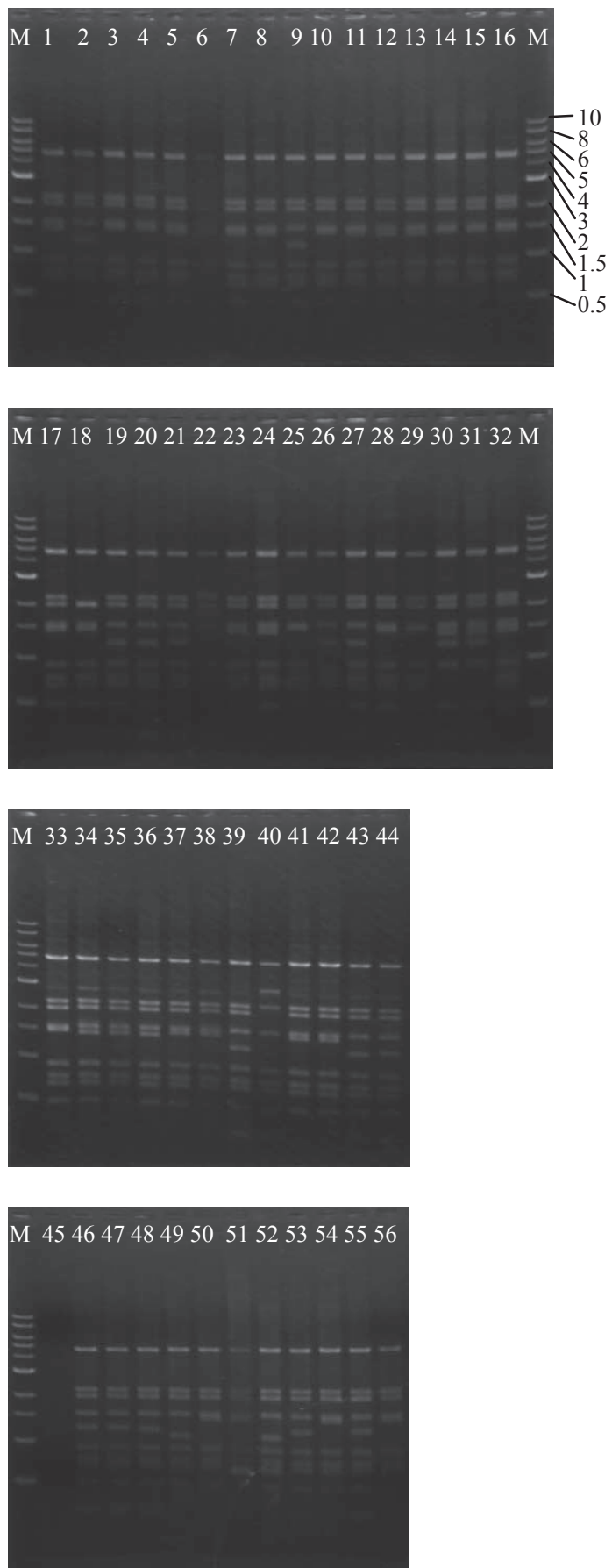

Fig. 2. LA-PCR-cpDNA amplified from Salvia (Lanes 1 29 and 32 48) and Ocimum species (Lanes 30 31) digested with $M f e I$ restriction enzyme. Numbers indicate the names of Salvia and Ocimum species as listed in order in Table 1. M is $1 \mathrm{~kb}$ DNA ladder marker (New England BioLabs, UK).

\section{Discussion}

Walker et al. (2004) grouped Salvia into Clade I of mainly Old World species, Clade II of mainly New World species and Clade III of Asian species. From the generated dendrogram, Salvia species were clustered into groups based on origin (Clebsch 2003) and was found almost in accordance with Walker et al. (2004) report despite the use of different part of the cpDNA. Group I is the basic clade for this collection of Salvia and contains five species, 
Table 3. Restriction enzymes and number of minimum, maximum, and polymorphic resultant fragments from LA-PCR-RFLP of cpDNA from Salvia and Ocimum species

\begin{tabular}{lcccccc}
\hline \multicolumn{7}{c}{ Restriction enzymes } \\
\hline Number of fragments & EcoRI & HindIII & $P v u$ II & NdeI & SmaI & MfeI \\
\hline Minimum & 8 & 4 & 1 & 2 & 3 & 8 \\
Maximum & 10 & 4 & 1 & 3 & 5 & 10 \\
Polymorphic & 9 & 3 & 0 & 3 & 3 & 10 \\
\hline
\end{tabular}

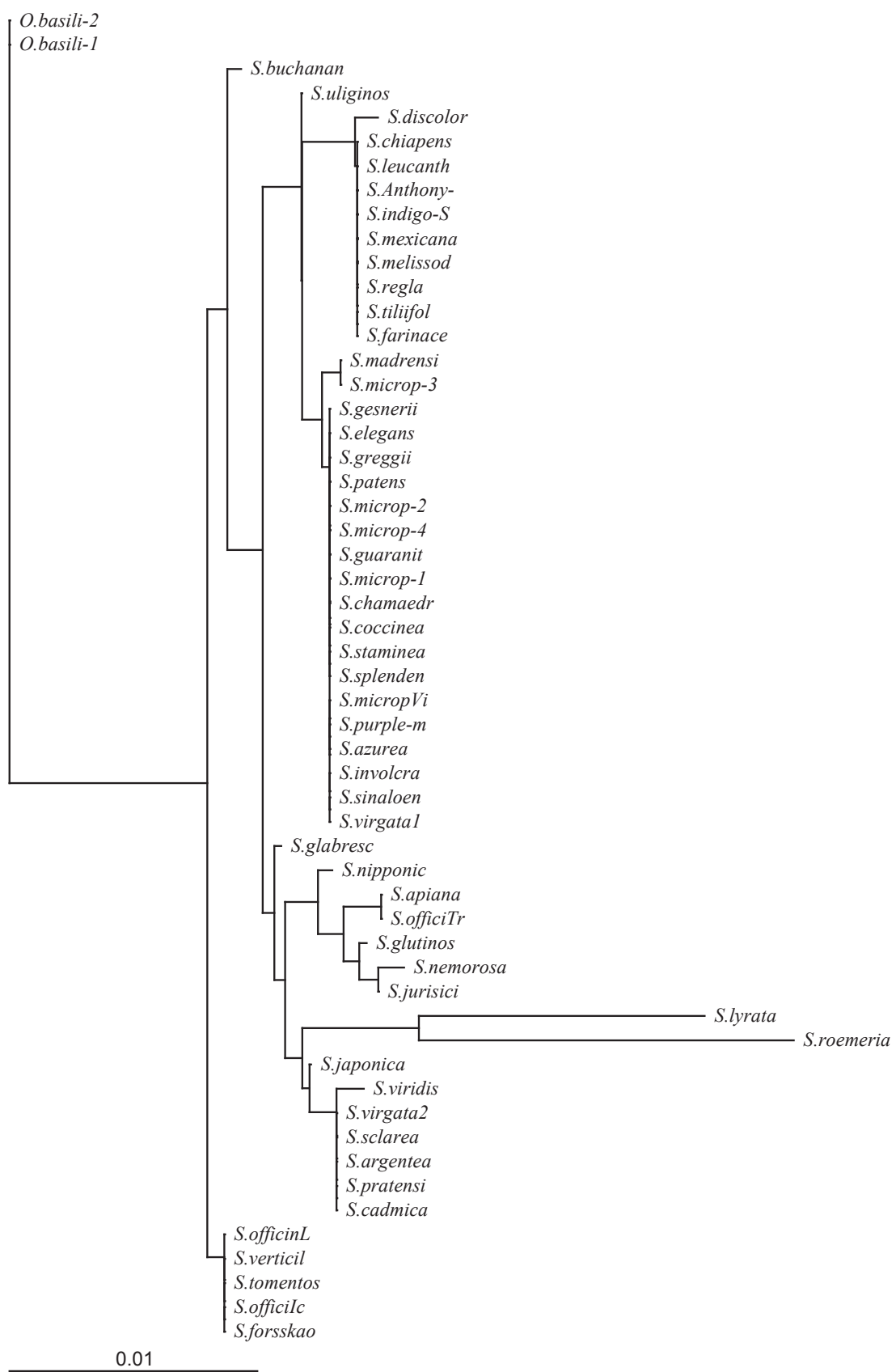

Fig. 3 Phylogenetic tree of 53 Salvia species and 2 Ocimum species obtained by neighbor-joining method based on LA-PCR-cpDNA-RFLP marker-based genetic similarity.

S. forsskaolii, S. verticillata, S. officinalis, S. officinalis 'Icterina', and $S$. tomentosa from northern Balkan, Central Europe, Western Asia, northern Mediterranean, and Asia Minor. S. buchananii of Mexico was the only species in group II and compose a sister clade with the rest of species that are designated as group III. Group III was divided into 2 major subgroups; Subgroup III-i is the most sophisticated and diverse clade and was subdivided into many other minor clades. The eastern Asia species include S. glabrescens, S. nipponica, and S. japonica that are 
native to Japan were scattered in this subgroup in consistence with a recent study of Japanese Salvia (Takano and Okada, 2010). Subgroup III-ia contains only S. glabrescens as a basal species for another 2 minor clades of subgroup IIIib. Subgroup III-ib1 includes S. lyrata and S. roemeriana of North and Central America in one subclade, while the other subclade contains $S$. japonica of Japan as a sister species of another subclade that includes $S$. argentea from southern Europe, $S$. viridis from the Mediterranean up to Iran, S. sclarea from the Mediterranean, northern Africa, and Central Asia, S. pratensis from Europe, northern Africa, and western Asia, S. cadmica from Asia Minor and S. virgata from California. Subgroup III-ib2 is of a wide range as reported before (Ibrahim et al. 2010). Salvia nipponica from Japan was also a basal species to $S$. officinalis 'Tricolor' from northern Mediterranean and Asia Minor and S. apiana from California. The presence of $S$. apiana in this subgroup is strange, because in the latest report (Ibrahim et al. 2010) it was in a separate subclade and sister to all other species. This could be due to a natural hybridization with Asian species and maternal inheritance of chloroplast genome. S. officinalis 'Tricolor' and $S$. apiana species were basal to $S$. glutinosa of Central France, Spain, Italy, Greece and Central Russia, which itself was basal to $S$. nemrosa of Eastern Europe and western Asia and S. jurisicii of Europe and southern Balkan area. This might be in consistency with Walker et al. (2004) who grouped S. glutinosa in a separate clade named III with other five species; $S$. digitaloides from China, S. fruticosa from eastern Mediterranean and southern Italy, S. nubicola from Afghanistan, Bhutan, India, Pakistan, southeastern Asia and Europe, S. barrelieri from North Africa, and $S$. hians from Kashmir. Subgroup III-ii of Latin and Central America species was also divided into subgroup III-iia that contained only $S$. uliginosa of Brazil, Paraguay and Argentina, subgroup III-iib included 2 minor clades; III-iib1 that accommodates ten species including $S$. discolor as the basic species for this subclade and they are only from South America, Central America, and Mexico. This is in consistence with a recent report that included some of the species in this study (Jenks et al. 2010). Group III-iib2 was also subdivided into two minor clades. Salvia madrensis and $S$. microphylla were basal to the other subclade of 18 species from South America, Central America and Mexico except S. virgata and S. staminea from California and Asia Minor up to Iran, respectively. S. virgata and $S$. staminea clustered in this last minor clade of group III-iib2 was also reported before in a study included different pair of primers and different part of cpDNA (Ibrahim et al. 2010). There are two possibilities for the presence of $S$. staminea in the Latin American group. One possibility is a natural hybridization between S. staminea and Latin or Central American species as a maternal donor of chloroplast genome. The other possibility might be a mislabeled plant.
This report shows that Salvia species under study can be divided into groups based on only one long PCR product from the chloroplast genome and one restriction enzyme at a time. A combination of two enzymes simultaneously in a double digestion may increase the resolution of results and lead to species specific markers (Parani et al. 2001). In general, all species of Salvia that included in this study or Ibrahim et al. (2010) and the report of Walker et al. (2004) were clustered based on origin. Salvia roemeriana showed AFLD as well as species-specific pattern against EcoRI, MfeI, HindIII, NdeI or SmaI restriction enzymes. Salvia lyrata expressed the same phenomenon and can also be identified from $S$. roemeriana as well as other species by EcoRI, MfeI, HindIII, NdeI or SmaI restriction enzymes. Ocimum species can be identified from Salvia based on the studied part of cpDNA digested with any of NdeI, SmaI or MfeI restriction enzymes. Natural hybridization and maternal inheritance of chloroplast genome might be the reason for the unique cluster of $S$. staminea from Asia Minor and Iran with South and Central America species. This case of $S$. staminea needs further investigation. Based on this report, most species of Salvia in Kyoto Botanical Garden are from South America, Central America, the Mediterranean and Asia Minor more than other parts of the world. This could be due to early day's travel of Japanese to South America, Central America and Asia Minor as well.

ACKNOWLEDGMENTS. This work was supported by a Grant-inAid (No 020518) from the Ministry of Education, Science, Sports and Culture of Japan. Samples of Salvia leaves were gifts from Kyoto Botanical Garden (Kyoto, Japan) to whom we express sincere gratitude.

\section{Literature Cited}

Arroyo-Garcia, R., Lefort, F., de Andres, M.T., Ibanaez, J., Borrego, J., Jouve, N., Cabello, F, Martinez-Zabater, J. M. 2002. Chloroplast microsatellite polymorphisms in Vitis species. Genome 45:1142-1149.

Badenes, M. L. and Parfitt, D. E. 1995. Phylogenetic relationships of the cultivated Prunus species from an analysis of chloroplast DNA variation. Theor. Appl. Genet. 90: 10351041.

Byrne, M., Macdonald, B. and Brand, J. 2003. Phylogeography and divergence in the chloroplast genome of Western Australian Sandalwood (Santalum spicatum). Heredity 91: 389-395.

Cato, S. A. and Richardson, T. E. 1996. Inter- and intra-specific polymorphism at chloroplast SSR loci and the inheritance of plastids in Pinus radiata D. Don. Theor. Appl. Genet. 93: 587-592.

Claßen-Bockhoff, R., Wester, P. and Tweraser, E. 2003. The staminal lever arm mechanism in Salvia - a review. Plant Bio. 5: 33-41.

Clebsch, B. 2003. The new book of Salvias, sages for every garden. Timber Press, Portland, Oregon, U.S.A.

Cronn, R. C., Small, R. L., Haselkorn, T., Wendel, J. 2002. Rapid diversification of the cotton genus (Gossypium: Malvaceae) revealed by analysis of sixteen nuclear and chloroplast genes. Am. Journ. Bot. 89: 707-725.

Demesure, B., Sodzi, N., Petit, R. J. 1995. A set of universal primers for amplification of polymorphic non-coding regions of mitochondrial and chloroplast DNA in plants. 
Mol. Eco. 14: 129-131

Demesure, B., Comps, B., Petit, R. J. 1996. Chloroplast DNA phylogeography of the common beech (Fagus sylvatica L.) in Europe. Evolution 50: 2515-2520.

Dhingra, A. and Folta, M. K. 2005. ASAP: Amplification, sequencing and annotation of plastomes. BMC Genomics 6: 176 doi:10.1186/1471-2164-6-176.

Dumolin, S., Demesure, B. and Petit, R. J. 1995. Inheritance of chloroplast and mitochondrial genomes in pedunculate oak investigated with an efficient PCR method. Theor. Appl. Genet. 91: 1253-1256.

Felsenstein, J. 2005. PHYLIP (Phylogeny Inference Package) version 3.6. Distributed by the author, Department of Genome Sciences, University of Washington, Seattle $<$ http://evolution.genetics.- washington.edu/phylip.html $>$ (Website accessed on 10th Jan.2011).

Gielly, L., Taberlet, P. 1994. The use of chloroplast DNA to resolve plant phylogenies: noncoding versus $r b c \mathrm{~L}$ sequence. Mol. Biol. Evol. 11: 769-777.

Govindaraju, D., Lewis, P. and Cullis, C. 1992. Phylogenetic analysis of pines using ribosomal DNA restriction fragment length polymorphisms. Plant Syst. Evol. 179: 141-153.

Heinze, B. 2007. A database of PCR primers for the chloroplast genomes of higher plants. Plant Meth. 3: 4 doi:10.1186/ 1746-4811-3-4

Hiratsuka, J., Shimada, H., Whittier, R., et al. 1989. The complete sequence of the rice (Oryza sativa) chloroplast genome: intermolecular recombination between distinct tRNA genes accounts for a major plastid DNA inversion during the evolution of the cereals. Mol. Gen. Genet. 217: 185194.

Huang, J. C. and Sun, M. 2000. Genetic diversity and relationships of sweetpotato and its wild relatives in Ipomoea series Batatas (Convolvulaceae) as revealed by inter-simple sequence repeat (ISSR) and restriction analysis of chloroplast DNA. Theor. Appl. Genet. 100: 1050-1060.

Hupfer, H., Swiatek, M., Hornung, S., Herrmann, R. G., Maier, R. M., Chiu, W. L. and Sears, B. 2000. Complete nucleotide sequence of the Oenothera elata plastid chromosome, representing plastome I of the five distinguishable Euoenothera plastomes. Mol. Gen. Genet. 263: 581-585.

Ibrahim, R. I. H., Azuma, J. I. and Sakamoto, M. 2006. Complete nucleotide sequence of the cotton (Gossypium barbadense L.) chloroplast genome with a comparative analysis of sequences among 9 dicot plants. Gen. Genet. Syst. 81: 311-321.

Ibrahim, R. I. H., Azuma, J. I. and Sakamoto, M. 2007. PCRRFLP analysis of the whole chloroplast DNA from three cultivated species of cotton (Gossypium L.). Euphytica 156: 47-56.

Ibrahim, R. I. H., Azuma, J. I. and Sakamoto, M. 2010. LAPCR-RFLP analysis of the chloroplast DNA in some species of the genus Salvia L. Chrom. Bot. 5: 95-103.

Ishii, T., Xu, Y. and McCouch, S. R. 2001. Nuclear- and chloroplast-microsatellite variation in A-genome species of rice. Genome 44: 658-666.

Jenks, A. A, Walker, J. B. and Kim, S. C. 2010. Evolution and origins of the Mazatec hallucinogenic sage, Salvia divinorum (Lamiaceae): a molecular phylogenetic approach. Journ. Plant Res. DOI 10.1007/s10265-0100394-6.

Kanno, A., Watanabe, N., Nakamura, I. and Hirai, A. 1993. Variation in chloroplast DNA from rice (Oryza sativa): differences between deletions mediated by short directrepeat sequences within a single species. Theor. Appl. Genet. 86: 579-584.

Kato, T., Kaneko, T., Sato, S., Nakamura, Y. and Tabata, S. 2000. Complete structure of the chloroplast genome of a legume, Lotus japonicus. DNA Res. 7: 323-330.

Krupkin, A. B., Liston, A. and Strauss, S. H. 1996. Phylogenetic analysis of the hard pines (Pinus subgenus Pinus,
Pinaceae) from chloroplast DNA restriction-site analysis. Am. Journ. Bot. 83: 489-498.

Lakshmi, M, Senthilkumar, P., Parani, M., Jithesh, M. N. and Parida, A. K. 2000. PCR-RFLP analysis of chloroplast gene regions in Cajanus (Leguminosae) and allied genera. Euphytica 116: 243-250.

Maier, R. M., Neckermann, K., Igloi, G. L. and Kössel, H. 1995. Complete sequence of the maize chloroplast genome: gene content, hotspots of divergence and fine tuning of genetic information by transcript editing. Journ. Mol. Biol. 251: 614-628.

Morton, B. R. and Clegg, M. T. 1995. Neighboring base composition is strongly correlated with base substitution bias in a region of the chloroplast genome. Journ. Mol. Evol. 41: 597-603.

Nei, M. and Li, W. H. 1979. Mathematical model for studying genetic variation in terms of restriction endonucleases. Proc. Natl. Acad. Sci. U.S.A. 76: 5269-5273.

Ogihara, Y., Terachi, T. and Sasakuma, T. 1988. Intramolecular recombination of chloroplast genome mediated by short direct-repeat sequences in wheat species. Proc. Natl. Acad. Sci. U. S. A. 85: 8573-8577.

Ogihara, Y., Terachi, T. and Sasakuma, T. 1991. Molecular analysis of the hot spot region related to length mutations in wheat chloroplast DNAs: I. Nucleotide divergence of genes and intergenic spacer regions located in the hot spot region. Genetics 129: 873-884.

Page, R. D. M. 1996. TreeView: An application to display phylogenetic trees on personal computers. Computer Applications in the Biosciences 12: 357-358.

Palmer, J. D. 1987. Chloroplast DNA evolution and biosystematic uses of chloroplast DNA variation. Am. Nat. 130: 6-29.

Parani, M., Lakshmi, M., Ziegenhagen, B., Fladung, M., Senthilkumar, P. and Parida, A. 2000. Molecular phylogeny of mangrove VII. PCR-RFLP of $t r n \mathrm{~S}-p s b \mathrm{C}$ and $r b c \mathrm{~L}$ gene regions in 24 mangrove and mangrove-associate species. Theor. Appl. Genet. 100: 454-460.

Parani, M., Rajesh, K., Lakshmi, M., Parducci, L., Szmidt, A. E. and Parida, A. 2001. Species identification in seven small millet species using polymerase chain reaction restriction fragment length polymorphism of trnS-psbC gene region. Genome 44: 495-499.

Parducci, L. and Szmidt, A. E. 1999. PCR-RFLP analysis of cpDNA in the genus Abies. Theor. Appl. Genet. 98: 802808.

Parducci, I., Szmidt, A. E., Madaghiele, A., Anzidei, M. and Vendramin, G. G. 2001. Genetic variation at chloroplast microsatellites (cpSSRs) in Abies nebrodensis (Lojac.) Mattei and three neighboring Abies species. Theor. Appl. Genet. 102: 733-740.

Powell, W., Morgante, M., McDevitt, R., Vendramin, G. and Rafalski, J. 1995. Polymorphic simple sequence regions in chloroplast genomes: applications to the population genetics of pines. Proc. Natl. Acad. Sci. U. S. A. 99: 77597763.

Ridgway, K. P., Duck, J. M. and Young, J. P. W. 2003. Identification of roots from grass swards using PCRRFLP and FFLP of the plastid trnL (UAA) intron. BMC Ecology 3: 8.doi:10.1186/1472-6785-3-8

Schaal, B. A., Hayworth, D. A., Olsen, K. M., Rauscher, J. T. and Smith, W. A. 1998. Phylogeographic studies in plants: problems and prospects. Mol. Ecol. 7: 465-474.

Shen, L., Chen, X. Y., Zhang, X., Li, Y. Y., Fu, C. X. and Qiu, Y. X. 2005. Genetic variation of Ginkgo biloba L. (Ginkgoaceae) based on cpDNA PCR-RFLPs: inference of glacial refugia. Heredity 94: 396-401.

Shih, F. L., Cheng, Y. P., Hwang, S. Y. and Lin, T. P. 2006. Partial concordance between nuclear and organelle DNA in revealing the genetic divergence among Quercus glauca (Fagaceae) populations in Taiwan. Int. Journ. Plant Sci. 167: 863-872

Shimada, H. and Sugiura, M. 1991. Fine structural features of 
the chloroplast genome: comparison of the sequenced chloroplast genomes. Nucleic Acids Research 19: 983995.

Stehlik, F., Blattner, R., Holderegger, R. and Bachmann, K. 2002. Nunatak survival of the high Alpine plant Eritrichium nanum (L.) Gaudin in the central Alps during the ice ages. Mol. Ecol. 11: 2027-2036.

Stehlik, I. 2002. Glacial history of the alpine herb Rumex nivalis (polygonaceae): a comparison of common phylogeographic methods with nested clade analysis. Am. Journ. Bot. 89: 2007-2016.

Strauss, S. H. and Doerksen, A. H. 1990. Restriction fragment analysis of pine phylogeny. Evolution 44: 1081-1096.

Taberlet, P., Gielly, L., Pautou, G., and Bouvet, J. 1991. Universal primers for amplification of three non-coding regions of chloroplast DNA. Plant Mol. Biol. 17: 11051109

Takano, A. and Okada, H. 2010. Phylogenetic relationships among subgenera, species, and varieties of Japanese Salvia L. (Lamiaceae). Journ. Plant Res. DOI 10.1007/ s10265-010-0367-9.

Tsai, L. C., Yu, Y. C., Hsieh, H. M., Wang, J. C., Linacre, A. and Lee, J. C. I. 2006. Species identification using sequences

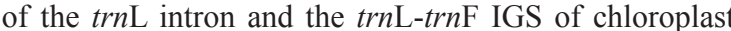
genome among popular plants in Taiwan. Forensic Sci. Int. 164: 193-200.

Tsai, L. C., Wang, J. C., Hsieh, H. M., Liu, K. L., Linacre, A. and Lee, J. C. I. 2008. Bidens identification using the noncoding regions of chloroplast genome and nuclear ribosomal DNA. Forensic Sci. Int. Genet. 2: 35-40.

Tsumura, Y., Kawahara, T., Wickneswari, R. and Yoshimura, K. 1996. Molecular phylogeny of Dipterocarpaceae in southeast Asia using RFLP of PCR-amplified chloroplast genes. Theor. Appl. Genet. 93: 22-29.

Van Droogenbroeck, B., Kyndt, T., Maertens, I., RomeijnPeeters, E., Scheldeman, X., Romero-Motochi, J. P, Van Damme, P., Goetghebeur, P. and Gheysen, G. 2004 Phylogenetic analysis of the highland papayas (Vasconcellea) and allied genera (Caricaceae) using PCR-
RFLP. Theor. Appl. Genet. 108: 1473-1486.

Vekemans, X., Hardy, O., Berken, B., Fofana, B. and Baudoin, J. B. 1998. Use of PCR-RFLP on chloroplast DNA to investigate phylogenetic relationships in the genus Phaseolus. Biotechnol. Agron. Soc. Environ. 2: 128-134.

Wagstaff, S. J., Olmstead, R. G. and Cantino, P. D. 1995. Parsimony analysis of cpDNA restriction site variation in subfamily nepetoideae (Labiatae). Am. Journ. Bot. 82: 886-892.

Walker, J. B., Sytsma, K. J., Treutlein, J. and Wink, M. 2004 Salvia (Lamiaceae) is not monophyletic: implications for the systematics, radiation, and ecological specializations of Salvia and tribe Mentheae. Am. Journ. Bot. 91: 11151125.

Walker, J. B. and Sytsma, K. J. 2007. Staminal evolution in the genus Salvia (Lamiaceae): molecular phylogenetic evidence for multiple origins of the staminal lever. Ann. Bot. 100:375-391

Wang, X. R. and Szmidt, A. E. 1994. Hybridization and chloroplast DNA variation in a Pinus species complex from Asia. Evolution 48: 1020-1031.

Wang, G. Z., Matsuoka, Y. and Tsunewaki, K. 2000. Evolutionary features of chondriome divergence in Triticum (wheat) and Aegilops shown by RFLP analysis of mitochondrial DNAs. Theor. Appl. Genet. 100: 221231

Wei W, Youliang Z, Li C, Yuming W, Zehong Y, Ruiwu Y (2005) PCR-RFLP analysis of cpDNA and mtDNA in the genus Houttuynia in some areas of China. Hereditas 142: 24-32.

Xu DH, Abe J, Kanazawa A, Gai JY, Shimamoto Y (2001) Identification of sequence variations by PCR-RFLP and its application to the evaluation of cpDNA diversity in wild and cultivated soybeans. Theor Appl Genet 102: 683-688.

Ziegenhagen B, Kormutak A, Schauerte M, Scholz F (1995) Restriction-site polymorphism in chloroplast DNA of Silver Fir (Abies alba Mill.). For Genet 2: 99-107. 